\title{
KEMAMPUAN PERANGKAT DESA DALAM MENYUSUN LAPORAN KEUANGAN PROGRAM DANA DESA STUDI KASUS PADA DESA AMBAR HALIM KECAMATAN PINTU POHAN MERANTI KABUPATEN TOBA SAMOSIR
}

\author{
Uswatun Hasanah, Awaluddin \\ Fakultas Ekonomi Universitas Tjut Nyak Dhien, Program Studi Akuntansi \\ Email:Uswah.hana@yahoo.com
}

\begin{abstract}
The purpose of this study is to discuss how the level of ability of village officials in preparing financial reports. The method used was a case study through interviews with village officials who made financial programs in Ambar Halim Village, Pintu Pohan Meranti sub-District, Toba Samosir District. The study found that village officials in preparing financial reports were not optimal. Some of the obstacles faced by village officials in preparing financial reports of the village fund programs are training conducted by village officials and the ability of village officials to understand accounting is still not optimal
\end{abstract}

Keywords: Financial Reports, Village Funds

\begin{abstract}
Abstrak
Tujuan penelitian ini untuk mengetahui bagaimana kemampuan perangkat desa dalam menyusun laporan keuangan program dana desa serta kendala-kendala yang dihadapi. Metode yang digunakan adalah studi kasus melalui wawancara kepada perangkat desa yang bertugas membuat laporan keuangan program dana desa di Desa Ambar Halim kecamatan Pintu Pohan Meranti kabupaten Toba samosir. Penelitian ini menemukan bahwa kemampuan perangkat desa dalam menyusun laporan keuangan belum maksimal. Beberapa kendala yang dihadapi perangkat desa dalam menyusun laporan keuangan program dana desa antara lain kurang memadainya pelatihan-pelatihan untuk menyusun laporan keuangan program dana desa serta kemampuan perangkat desa dalam memahami akuntansijuga masih belum maksimal.
\end{abstract}

Kata kunci: Laporan Keuangan, Dana Desa

\section{Pendahuluan}

Penggunaan Dana Desa diprioritaskan untuk membiayai pembangunan dan pemberdayaan masyarakat yang ditujukan untuk meningkatkan kesejahteraan masyarakat desa, peningkatan kualitas hidup manusia serta penanggulangan kemiskinan dan dituangkan dalam Rencana Kerja
Pemerintah Desa, yang berpedoman pada pedoman teknis yang ditetapkan oleh bupati/walikota mengenai kegiatan yang dibiayai dari Dana Desa.

Menurut Candra (2016) pembangunan desa mempunyai peran penting dan strategis dalam rangka pembangunan Nasional dan Pembangunan daerah, karena didalamnya 
Value Jurnal IImiah Akuntansi Keuangan dan Bisnis

Vol. 1 No. 1 Bulan April - September 2020

ada unsur pemerataan pembangunan dan hasil-hasilnya serta menyentuh secara langsung kepentingan sebagian besar masyarakat yang bermukim di pedesaan dalam rangka upaya meningkatkan kesejahteraan mereka. Dalam pembangunan desa pemerintahan desa berkedudukan sebagai subsistem dari sistem penyelenggaraan pemerintahan di Indonesia, sehingga desa memikili kewenangan, tugas dan kewajiban untuk mengatur dan mengurus kepentingan masyrakat sendiri. Dalam menyelenggaraan kewenangan, tugas dan kewajiban desa dalam penyelenggaraan pemerintahan maupun pembangunan dibutuhkan sumber pendapatan desa.

Menurut Wayan (2016) menyatakan bahwa pembangunan desa merupakan model pembangunan partisipatif yaitu suatu sistem pengelolaan pembangunan bersama-sama, yang direncanakan, dilaksanakan dan dievaluasi secara musyawarah, mufakat dan gotong royong, yang merupakan cara hidup masyarakat yang telah lama berakar budaya wilayah Indonesia.

Dana desa pertama kali digulirkan pada tahun 2015 dengan jumlah anggaran sebesar Rp 20,76 triliun. Sejauh ini Pemerintah Pusat telah mengalokasikan anggaran dana desa mencapai Rp 257 triliun sejak 2015 hingga 2019. Dengan rincian Rp
20,67 triliun (2015), Rp 46,98 triliun (2016), Rp 60 triliun (2017), Rp 60 triliun (2018), dan Rp 70 triliun (2019). Dana desa tersebut diberikan ke seluruh desa di Indonesiadengan formula 77 persen dibagi rata ke seluruh desa. Kemudian 20 persen dialokasikan untuk tambahan secara proporsional kepada desa berdasarkan jumlah penduduk, tingkat kemiskinan, tingkat kesulitan geografis dan luas wilayah. Kemudian, tiga persen dialokasikan untuk tambahan kepada desadesa yang berstatus tertinggal Kompas.com (2019)

Sejak digulirkannya dana desa hingga tahun 2019 desa-desa di Indonesia telah mampu membangun infrastruktur dasar dalam jumlah yang sangat besar dan masif, yang sangat dibutuhkan untuk memenuhi kebutuhan hidup dasar dan juga untuk membantu kegiatan ekonomi di desa. seperti terbangunnya 1.140 .378 meter jembatan, jalan desa 191.600 kilometer, pasar desa sebanyak 8.983 unit, kegiatan BUMDesa sebanyak 37.830 unit, embung desa sebanyak 4.175 unit, sarana irigasi sebanyak 58.931 unit. Selain itu, dana desa juga telah turut membangun sarana prasarana penunjang kualitas hidup masyarakat desa melalui pembangunan 959.569 unit saranaair bersih, 240.587 unit Mandi Cuci Kakus (MCK), 9.692 unit Polindes, 50.854 unit 
Value Jurnal Ilmiah Akuntansi Keuangan dan Bisnis

Vol. 1 No. 1 Bulan April - September 2020

PAUD, 24.820 unit Posyandu, serta drainase

29.557.922. Kompas.com (2019)

Menurut Eko Putro Sandjojo,Menteri

Desa, Pembangunan Daerah Tertinggal dan

Transmigrasi dalam kompas.com (2019)

Adanya program dana desa terbukti efektif dan telah berhasilmengurangi kemiskinan di desa-desa sertapenurunan angka stunting dari 37 persen menjadi 30 persen, peningkatan pendapatan per kapita hampir 50 persen, pembukaan lapangan kerja melalui program Padat Karya Tunai (PKT), BUMDes, desa wisata, angka pengangguran di desa turun dibandingkandengan kota dan Gini ratio di desa terus meningkat. Bahkan, jumlah desa tertinggal juga mengalami penurunan dan juga terjadi peningkatan jumlah desa berkembang. Pada Tahun 2019 penggunaan dana desa direncanakan digeser untuk pemberdayaan ekonomi dan pemberdayaan masyarakat desa. Maka, bagi desa yang sudah memiliki infrastruktur yang cukup, untuk kedepannya dapat mengalihkan program dana desa ke pembangunan pemberdayaan ekonomi dan pemberdayaan masyarakat desanya agar pertumbuhan ekonomi desa dan pendapatan masyarakat desa juga turut meningkat.

Salah satu cara pemerintah memberikan perhatian khusus dalam pembangunan dan pemberdayaan masyarakat desa dibuatlah Undang-undang no 6 Tahun 2014 tentang desa. Menurut Nyimaas (2016) menyatakan Undangundang ini membawa perubahan besar yang mendasar bagi kedudukan dan relasi desa dengan daerah dan pemerintah meliputiaspek kewenangan,perencanaan, pembangunan, keuangan dan demikrasi desa. Melalui UU ini kedudukan desa semakin kuat. UU ini dengan jelas menyatakan bahwa desa dan adat desa mendapat perlakuan yang sama dari pemerintah dan pemerintah daerah.

Desa diberikan otonomi untuk mengatur dan mengurus kepentingan masyarakat berdasarkan hak asal-usul, adat istiadat dan nilai sosial budaya masyarakat desa, serta menetapkan dan mengelola kelembagaan desa. Menurut Solikhah (2018) dengan disahkannya UU No 6 tahun 2014 tentang desa,desa telah diberikan kesempatan yang besar untuk mengurus tata pemerintahannya sendiri serta melaksanakan pemebangunan untuk meningkatkan kesejahteraan dan kualitas masyarakat desa, selain itu diharapkan pemerintah desa lebih mandiri dalam mengelola pemerintahan dan berbagai sumberdaya alam yang dimiliki, termasuk didalamnya pengelolaan keuangan dan kekayaan milik desa. 
Value Jurnal Ilmiah Akuntansi Keuangan dan Bisnis

Vol. 1 No. 1 Bulan April - September 2020

Menurut Mutia (2017) berbagai peraturan dari pemerintah tidak dimaksud untuk mempersulit pemerintahan desa untuk pengelola dana desa, melainkan agar dapat dimanfaatkan dengan maksimal demi kemajuan desa sekaligus dapat dipertanggung jawabkan sebaik-baiknya. Namun ada beberapa perangkat desa yang merasa terbebani dengan adanya dana desa, hal ini terkait dengan pertanggung jawaban dana tersebut. Menurut Ismail (2016)banyak pihak yang menganggap kemampuan aparat desa yang masih rendah dan belum siap justru dikhawatirkan akan membawa pada meja hijau. Dalam hal dalam pengelolaan dana desa, akan ada resiko terjadinya kesalahan baik bersifat administratif maupun substantif yang mengakibatkan terjadinya permasalaahan hukum mengingat belum memadainya kompetensi kepala desa dan aparat desa dalam hal penatausahaan, pelaporan dan pertanggung jawaban keuangan desa.

Kualitas pelaporan keuangan sektor public adalah kualitas sumber daya manusia. Dengan kata lain, rendahnya pemahaman tentang akuntasi pemerintah berpengaruh terhadap pembuatan laporan keuangan serta transparansi dan akuntabilitas pengelolaan keuangan daerah, banyak penelitian membuktikan bahwa masih rendahnya SDM pemerintah daerah dalam melakukan pengelolaan dan pelaporan keuangan, kualitas pelaporan keuangan sektor publik di Indonesia masih mengalami berbagai kendala, belum baiknya sistem akuntasiyang diterapkan dan rendahnya pemahaman terhadap akuntansi merupakan beberapa kendala yang dihadapi pihak publik di Indonesia, masalah tersebut baik dari pemerintahan pusat sampai pemerintahan terendah Ismail (2016).

Berdasarkan latar belakang di atas penelitian ini bermaksud untuk mengetahui bagaimana kemampuan perangkat desadalam menyusun laporan keuangan program dana desa serta kendala-kendala yang dihadapi pada desa Ambar Halim Kecamatan Pintu Pohan Meranti kabupaten Tobasa .

\section{Tinjauan Pustaka}

\subsection{Dana Desa}

Berdasarkan UU No. 6 Tahun 2014 tentang Desa, dana desa yang bersumber dari APBN mencakup Dana Desa (DD) dan Alokasi Dana Desa (ADD). Dana Desa (DD) merupakan alokasi anggaran yang bersumber dari belanja pusat dengan mengefektifkan program yang berbasis desa secara merata dan berkeadilan, sedangkan Alokasi Dana Desa (ADD) merupakan 
Value Jurnal IImiah Akuntansi Keuangan dan Bisnis

Vol. 1 No. 1 Bulan April - September 2020

bagian dari dana perimbangan keuangan pusat dan daerah, yakni 10\% (sepuluh perseratus) dari dana perimbangan yang diterima Kabupaten/Kota dalam Anggaran Pendapatan dan Belanja Daerah (APBD) setelah dikurangi Dana Alokasi Khusus (DAK). Dana desa yang bersumber dari APBN ini diperuntukan untuk membiayai penyelenggaraan pemerintahan, pembangunan, pemberdayaan masyarakat desa, dan kemasyarakatan.

Menurut Mutia dan liliana (2017) dana desa filosofinya adalah meningkatkan kesejahteraan masyarakat desa dan adanya pemerataan dalam pembangunan yang dilaksanakan di desa dengan pelayanan kepada publik yang meningkatkan, perekonomian desa yang maju dan mengurangi kesenjangan pembangunanantar desa, serta memperkuat masyakat desa tidak hanya sebagai objek tapi bertindak sebagai subjek dalam pembangunan.

\subsection{Keuangan Desa}

Dalam UU Desa, keuangan desa adalah semua hak dan kewajiban desa yang dapat dinilai dengan uang serta segala sesuatu berupa uang dan barang yang berhubungan dengan pelaksanaan hak dan kewajiban desa. Hak dan kewajiban tersebut menimbulkan pendapatan, belanja, dan pembiayaan yang perlu diatur dalam pengelolaan keuangan desa yang baik. Siklus pengelolaan keuangan desa meliputi perencanaan, pelaksanaan, penatausahaan, pelaporan, dan pertanggung jawaban,dengan periodisasi 1 (satu) tahun anggaran, terhitung mulai tanggal 1 Januari sampai dengan 31 Desember.

Belanja Desa diprioritaskan untuk memenuhi kebutuhan pembangunan yang disepakati dalam Musyawarah Desa dan sesuai dengan prioritas Pemerintah Daerah Kabupaten/Kota, Pemerintah Daerah Provinsi, dan Pemerintah.

\subsection{Pengelolaan Keuangan Dana Desa}

Berdasarkan Permendagri Nomor

113 Tahun 2014 tentang "Pengelolaan keuangan desa bahwa yang dimaksud pengelolaan keuangan desa adalah keseluruhan kegiatan yang meliputiperencanaan, pelaksanaan, penatausahaan, pelaporan, dan pertanggungjawaban keuangan desa, Keuangan desa dikelola berdasarkan asasasas transparan, akuntabel, partisipatif serta dilakukan dengan tertib dan disiplin anggaran sesuai dengan Permendagri 113 Tahun 2014.

Menurut Muhammad Arif (2007) Pengelolaan keuangan desa adalah keseluruhan kegiatan yang meliputi perencanaan, penganggaran, penatausahaan, 
Value Jurnal IImiah Akuntansi Keuangan dan Bisnis

Vol. 1 No. 1 Bulan April - September 2020

pelaporan, pertanggungjawaban, dan pengawasan keuangan desa. Srirejeki (2015) menyatakan bahwa pengelolaan keuangan desa merupakan upaya untuk mendukung penyelenggaraan pemerintahan desa, pelaksanaan pembangunan desa, pembinaan kemasyarakatan desa dan pemberdayaan masyarakat desa. Pengelolaan keuangan dan kekayaan desa secara mandiri yang diamanatkan dalam UU No. 6 Tahun 2014 memang menjadikan desa sebagai subjek yang berperan aktif sebagai motor penggerak pembangunan, namun di lain pihak memberikan beban tanggung jawab yang besar bagi pemerintah desa. Pemerintah desa diharapkan dapat mengelola keuangan desa dengan baik, jujur, dan tidak melakukan penyelewengan.

Struktur penyusunan dan pembentukan dasar hukum pengelolaan keuangan desa dimulai dengan terbitnya Undang-Undang Nomor 6 Tahun 2014 tentang Desa yang pengaturannya dimulai dari Pasal 71 hingga Pasal 75. Dilanjutkan oleh Peraturan Pemerintah Nomor 43 Tahun 2014 tentang Peraturan Pelaksana UndangUndang Nomor 6 Tahun 2014 tentang Desa sebagaimana diubah dengan Peraturan Pemerintah Nomor 47 Tahun 2015 yang pengaturannya dimulai dari Pasal 90 hingga Pasal 106, dan Peraturan Menteri Dalam
Negeri Nomor 113 Tahun 2014 tentang Pengelolaan Keuangan Desa.

Di dalam pengaturannya, peraturan perundang-undangan secara berjenjang telah mengatur mengenai pengelolaan keuangan desa. Dimulai dengan Undang-Undang Nomor 6 Tahun 2014 tentang Desa sebagaimana diatur pada Pasal 75 ayat (3) yang berbunyi "ketentuan lebih lanjut mengenai keuangan Desa diatur dengan Peraturan Pemerintah.” Merujuk pada Pasal 75 ayat (3) Undang-Undang Nomor 6 Tahun 2014 tentang Desa, terbitlah Peraturan Pemerintah Nomor 43 Tahun 2014 tentang Peraturan Pelaksana Undang-Undang Nomor 6 Tahun 2014 tentang Desa sebagaimana diubah dengan Peraturan Pemerintah Nomor 47 Tahun 2015.

Berdasarkan Pasal 106 Peraturan Pemerintah Nomor 43 Tahun 2014 tentang Peraturan Pelaksana Undang-Undang Nomor 6 Tahun 2014 tentang Desa sebagaimana diubah dengan Peraturan Pemerintah Nomor 47 Tahun 2015 disebutkan bahwa, "ketentuan lebih lanjut mengenai pengelolaan keuangan desa diatur dalam Peraturan Menteri yang menyelenggarakan urusan pemerintahan di bidang pemerintahan dalam negeri”. Sedangkan sebagaimana diatur di dalam Pasal 105 Peraturan Pemerintah Nomor 43 
Value Jurnal IImiah Akuntansi Keuangan dan Bisnis

Vol. 1 No. 1 Bulan April - September 2020

Tahun 2014 tentang Peraturan Pelaksana Undang-Undang Nomor 6 Tahun 2014 tentang Desa sebagaimana diubah dengan Peraturan Pemerintah Nomor 47 Tahun2015, disebutkan bahwa, "Pengadaan barang dan/atau jasa di desa diatur dengan Peraturan Bupati/Walikota dengan berpedoman pada ketentuan peraturan perundang-undangan.”

\subsection{Pelaporan Dana desa}

Peraturan Menteri Keuangan Republika Indonesia No 49/PMK07/2016 BAB V Pelaporan pasal 25: Kepala Desa menyampaikan laporan realisasi penggunaan Dana Desa setiap tahap kepada bupati/walikota

1. Laporan realisasi penggunaan Dana Desa sebagaimana dimaksud pada ayat

(1) terdiri atas:

a. Laporan realisasi penggunanaan

Dana Desa tahun angggaran sebelumnya dan

b. Laporan realisasi penggunaan Dana Desa tahap I

2. Laporan realisasi penggunaan Dana Desa tahun anggaran sebelumnya sebagaimana dimaksud pada ayat (2) huruf a disampaikan paling lambat minggu kedua bulan Februari tahun anggaran berjalan
3. Laporan realisasi penggunaan Dana Desa tahap I sebagaimana dimaksud pada ayat (2) huruf b disampaikan paling lambat minggu keempat bulan Juli tahun anggaran berjalan

4. Laporan realisasi penyaluran sebagaimana dimaksud pada ayat (2) disusun sesuai format sebagaimana tercantum dalam lampiran VI yang merupakan bagian tidak terpisahkan dari Peraturan Mentri ini.

5. Bupati/walikota dapat memfasilitasi percepatan penyampaian laporan realisasi penggunaan Dana Desa sebagaimana dimaksud pada ayat (2)

IAI-KASP (2015) menjelaskanbahwa membuat laporan keuangan merupakan tahap akhir dari siklus akuntansi. Data laporan keuangan diambil dari seluruh proses yang dilakukan sampai dengan dibuatnya neraca lajur. Data yang diproses berdasarkan neraca lajur itulah digunakan sebagai dasar penyusunan laporan keuangan. Laporan keuangan desa menurut Permendagri No 113 tahun 2014 yang wajib dilaporkan oleh pemerintahan desa berupa:

1. Anggaran.

2. Buku kas.

3. Buku pajak.

4. Buku bank.

5. Laporan Realisasi Anggaran (LRA). 
Value Jurnal IImiah Akuntansi Keuangan dan Bisnis

Vol. 1 No. 1 Bulan April - September 2020

Berdasarkan Laporan Dana Desa dari desa-desa yang ada di wilayah kabupaten/kota, Bupati/Walikota menyampaikan Laporan Realisasi Penyaluran dan Konsolidasi PenggunaanDana Desa kepada Menteri keuangan dengan tembusan menteri yang menangani desa, menteri teknis/pimpinan lembaga pemerintah nonkementerian terkait, dan gubernur paling lambat minggu keempat bulan Maret tahun anggaran berikutnya.Sampai dengan panduan ini selesai disusun, belum ada ketentuan yang mengatur tentang format Laporan DanaDesa yang harus disampaikan oleh desa dan format kompilasi yang harus disusun oleh pemerintah kabupaten/kota. Hal yang bisa menjadi acuan dalam pengelolaan dana desa adalah Peraturan Menteri Desa, PDT dan Transmigrasi Nomor 5 Tahun 2015 tentang Prioritas Penggunaan Dana Desa Tahun2015. Hal yang perlu menjadi perhatian terkait penggunaan Dana Desa adalah SiLPA Dana Desa. Bupati/walikota memberikan sanksi administrasi berupa pengurangan Dana Desa jika SilPA-nyatidak wajar $( \pm 30 \%)$, yang dikarenakan penggunaan tidak sesuai dengan prioritas atau penyimpanan uang dalam bentuk deposito lebih dari 2 (dua) bulan. Juklak Bimkon Pengelolaan Keuangan Desa (2015)
2.5 Kompetensi Sumber daya Manusia (SDM)/Perangkat Desa

Pemerintah desa adalah kepala desa dibantu perangkat desa sebagai unsur penyelenggara Pemerintahan Desa. Berkenaan dengan pelaksanaan keuangan desa, UU No. 6 Tahun 2014 tentang Desa menyatakan bahwa kepala desa adalah pemegang kekuasaan pengelolaan keuangan Desa yang dalam pelaksanaannya dibantu oleh perangkat desa.

Desa sebagai organisasi pemerintah dibentuk dan didirikan dengan tujuan untuk memberikan pelayanan kepada masyarakat. Karena memiliki tugas yang berat,organisasi pemerintah harus dipimpin dan diisi oleh sumber daya manusia terpilih yangmemiliki semangat yang tinggi, komitmenyang utuh, dan kompetensi yang baik untuk melaksanakan tugas-tugas pemerintahan dan pembangunan Lembaga Administrasi Negara RI, (2009). Sumber daya manusia yang berkualitas juga dapat menghemat waktu pembuatan laporan keuangan, disebabkan karena sumber daya manusia tersebut telah mengetahui dan memahami apa yang akan dikerjakan dengan cepat dan baik sehingga penyajian laporan keuangan bisa tepat waktu Sembiring (2013).

Dalam ilmu manajemen personalia upaya peningkatan kualitas sumber daya 
Value Jurnal IImiah Akuntansi Keuangan dan Bisnis

Vol. 1 No. 1 Bulan April - September 2020

manusia disebut pengembangan karyawan.

Tujuan pengembangan karyawan adalah untuk memperbaiki efektifitas kerja karyawan dalam mencapai hasil-hasil kerja yang telah ditetapkan Heidjarachman(2008). Perangkat desa yang kurang memiliki pengetahuan dan keterampilan tentang bidang tugasnya akan mengalami kesulitan dan kelambatan dalambekerja, yang berakibat pada pemborosan bahan, waktu, dan biaya.

\section{Metode Penelitian}

Penelitian ini merupakan penelitian deskriptif dengan menggunakan pendekatan kualitatif, yaitu data yang dikumpulkan bukan berupa angka-angka, melainkan berasal dari wawancara dan dokumen resmi lainnya. Moleong (2007:6) mendefinisikan penelitian kualitatif adalah penelitian yang bermaksud untuk memahami fenomena tentang apa yang dialami oleh subjek peneliti secara holistik, dan dengan cara deskripsi dalam bentuk kata-katadan bahasa, pada suatu konteks khusus yang alamiah dan dengan memanfaatkan berbagai metode alamiah.Tingkat intervensi dalam penelitian ini adalah intervensi minimal. Sekaran (2006) menjelaskan bahwa dalam tingkat intervensi minimal, peneliti hanya mengumpulkan data dan tidak melakukan tindakan untuk mempengaruhi hasil penelitian. Horizon waktu dalam penelitian ini adalah cross sectional, dimana data yang dikumpulkan hanya sekali baik selama periode harian, mingguan atau bulanan.

Penelitian ini berlokasi di Desa Ambar Halim Kecamatan Pintu pohan meranti Kabupaten Toba Samosir. Lokasi penelitian diambil berdasarkan pertimbangan Peraturan Menteri Desa, Pembangunan Daerah Tertinggal, dan Transmigrasi Nomor 5 Tahun 2015 Pasal 3 mengenai Penetapan Prioritas Penggunaan Dana Desa Tahun 2015 bahwa dana desa diprioritaskan untuk membiayai belanja pembangunan dan pemberdayaanmasyarakat desa, salah satunya adalah dengan pengembangan potensi ekonomi lokal dan pemanfaatan sumber daya alam dan lingkungan secara berkelanjutan dibidang pangan, energi, kemaritiman dan kelautan, serta pariwisata dan industri. Kecamatan yang telah dipilih tersebut telah memiliki kriteria yang sesuai dengan penetapan prioritas penggunaan dana desa.

\section{Hasil Penelitian dan Pembahasan}

\subsection{Hasil Penelitian}

Ambar Halim adalah salah satu desa di Kecamatan Pintu Pohan Meranti, Kabupaten Toba Samosir, Provinsi Sumatra Utara, Indonesia. Desa Ambar Halim 
Value Jurnal IImiah Akuntansi Keuangan dan Bisnis

Vol. 1 No. 1 Bulan April - September 2020

kecamatan Pintu Pohan Meranti Kabupaten

Toba samosir adalah salah satu desa yang menerima bantuan program dana desa pada tahun 2019. Kabupaten Toba Samosir mendapat jatah alokasi dana desa sebesar Rp176.101.238.000. Dana tersebut akan diperuntukkan bagi 231 Desa yang ada di kabupaten tersebut. Menurut Henry Silalahi SE, MSi Kepala Dinas Pemberdayaan Masyarakat Desa, Perempuan dan Perlindungan Anak Kabupaten Tobasamosir dalam Mitrapol (2019) "Setiap desa rata rata mendapatkan alokasi dana sejumlah Rp 934 juta," Jumlah tersebut naik dibandingkan dari tahun sebelumnya, dimana pada tahun 2018 yang lalu hanya berkisar Rp.800 juta.

Prioritas dana desa saat ini sesuai permen no.16 Tahun 2018 yang mana lebih diprioritaskan kepada bidang pembangunan desa, pemberdayaan masyarakat desa, peningkatan aparatur desa, peningkatan kesejahteraan hidup dan penanggulangan kemiskinan dan pelayanan publik ditingkat desa.

Di dalam penyelenggaraan pemerintahan desa khususnya mengenai pengelolaan dan pertanggungjawaban keuangan di Desa Ambar Halim kecamatan pintu pohan meranti kabupaten Toba Samosir, berdasarkan hasil wawancara dengan kepala desa terdapat beberapa kendala yang dihadapi dalam menyusun laporan keuangan dan desa antara lain masih minimnya pelatihan untuk membuat laporan dana desa. Menurut beliau, pelatihan yang diikuti hanyalah 2 kali hal itu dirasa kurang memadai dalam memahami pembuatan laporan keuangan dana desa, dimana program ini baru dimulai pada tahun 2015. Kesulitan yang dihadapi terutama dibidang teknis pembuatan laporan keuangan. Meskipun begitu desa Ambar halim kecamatan pintu pohan meranti selalu membuat laporan keuangan program dana desa tepat waktu. Dalam pembuatan laporan keuangan kepala desa dibantu oleh Pemberdayaan Masyarakat Desa (PMD) jika mengalami kendala/kesulitan dalam pembuatan laporan keuangan dana desa.

\subsection{Pembahasan Penelitian}

Pengelolaan dana desa, menjadi beban bagi beberapa perangkat desa dalam pengelolaannya. Secara umum terdapat beberapa kendala dalam pengelolaan dana desa. kendala tersebut antara lain sulitnya desa mematuhi kerangka waktu siklus pengelolaan anggaran desa; belum tersedianya satuan harga baku barang atau jasa yang dijadikan acuan menyusun APBDes; rendahnya transparansi perencanaan, penggunaan, dan pertanggungjawab serta standarnya laporan 
Value Jurnal IImiah Akuntansi Keuangan dan Bisnis

Vol. 1 No. 1 Bulan April - September 2020

pertanggungjawaban yang dibuat desa yang rawan manipulasi dalam pelaporannya; penyusunan APBDes belum sepenuhnya mencerminkan kebutuhan desa. adanya kendala-kendala tersebut menunjukkan bahwa pemerintah perlu membuat peraturan tentang APBDes namun dalam proses penyusunannya melibatkan masyarakat serta memperhatikan prioritas kebutuhan desa; potensi desa dengan tujuan untuk peningkatan kesejahteraan, kemajuan untuk peningkatan kesejahteraan masyarakat desa. Di samping itu, dalam pengelolaan dana desa pasti bersentuhan dengan proses akuntansi yang memerlukan kemampuan sumber daya manusia yang mumpuni agar laporan keuangan yang dihasilkan benar sehingga sesuai standar yang berlaku. Teknologi juga akan sangat dibutuhkan dalam proses-proses pertanggungjawaban pengelolaan keuangan.

Beberapa Penelitian yang pernah dilakukan untuk mengetahui kemampuan perangkat desa dalam menyusun laporan keuangan dana desa diantaranya adalah Mangindaan dan Manossoh (2018) dengan judul penelitian kualitas sumber daya manusia pemerintah desa dalam pengelolaan dana desa yang bersumber dari anggaran pendapatan dan belanja Negara di kecamatan tabukan utara kab. Kepulauan sangihe menyimpulkan Secara umum, (1) kualitas SDM Pemerintah Desa dalam pengelolaan dana desa yang bersumber dari APBN di Kecamatan Tabukan Utara belum terlalu memadai. SDM Pemerintah Desa di Kecamatan Tabukan Utara belum terlalu siap dalam mengelola dana desa yang bersumber dari APBN.(2). Berdasarkan indikator knowledge, tingkat pendidikan aparat pemerintah desa adalah mayoritas lulusan SMA dan SMP, bahkan masih banyak yang hanya lulusan SD. (3). Berdasarkan indikator skills, masih banyak aparat Pemerintah Desa belum mengikuti pelatihan. Meskipun ada beberapa yang telah mengikuti pelatihan, materi pelatihan tidaklah efektif dalam meningkatkan SDM Pemerintah Desa untuk mengelola dana desa. (4). Berdasarkan indikator experience, rata - rata aparat Pemerintah Desa tidak memiliki pengalaman di bidang pengelolaan keuangan. Ada bendahara yangtidak dipilih berdasarkan experience, akan tetapi berdasarkan kedekatan dengan Kepala Desa. Pendamping desa yang seharusnya bertugas untuk memberikan saran dan masukan bagi Pemerintah Desa, juga tidak sesuai dengan yang diharapkan

(5) Berdasarkan indikator abilities, kemampuan komprehensif dalam 
Value Jurnal IImiah Akuntansi Keuangan dan Bisnis

Vol. 1 No. 1 Bulan April - September 2020

pengelolaan Pemerintah Desa di Kecamatan

Tabukan Utara masih sangat terbatas.

Penelitian yang dilakukan oleh Triani

dan handayani (2018) menyatakan bahwa dalam membuat laporan keuangan perangkat desa dibantu oleh tenaga pendamping desa untuk membantu administrasi pengelolaan dana desa. Namun mayoritas desa mengeluhkan tenaga pendamping desa yang keberadaannya justru menjadi beban desa. Tenaga pendamping desa tidak memiliki kemampuan dan keahlian terkait pengelolaan dana desa. kondisi tersebut menjadi kendala bagi desa untuk mempertangggungjawabkan penggu-naan dana desa.

Hal ini senada dengan penelitian Wijaya dan Roni (2019) yang berjudulpraktik pengelolaan keuangan desa dan faktor-faktor yang mempengaruhinya dengan lokasi penelitian di Desa Cilebut Timur Jawa Barat. Hasil dari penelitian ini menunjukkan aparat pemerintah desa cilebuttimur ternyata masih mempelajari mekanisme pengelolaan keuangan desa sendiri, karena minimnya pelatihan- pelatihan maupun pembekalan SDM pemerintah desa yang dibuat atau diselenggarakan oleh pemerintah. Kendala berikutnya ialah persoalan KKN yang masih terjadi di tingkat pemerintah daerah, bahkan
KKN terjadi mulai dari tahap penyusunan APBDes hingga ke tahap pertanggungjawaban mengenai APBDes. selain itu, masih ada pula kendala berupa keterlambatan dalam menetapkan peraturan daerah tentang APBD dan pemberitahuan mengenai pagu indikatif yang akan diberikan untuk desa, sehingga penyusunan APBDes menjadi ikut terlambat karena baru diketahui pagu anggaran yang diberikan untuk desa setelah APBD ditetapkan melalui peraturan daerah.

Penelitian yang dilakukan oleh Ismail, Widagdo dan widodo (2016) yang berjudul sistem akuntansi pengelolaan dana desa. Hasil penelitian menunjukkan bahwa permasalahan utama yang timbul adalah rendahnya pengetahuan dari kepala desa terkait pengelolaan keuangan desa berdasarkan Permendagri No. 113/2015. Menurut Marlinawati dan Wardani (2018) Pemerintah Desa Kabupaten Gunung Kidul khususnya pemerintah desa-desa yang berada di Kecamatan Gedang Sari hendaknya lebih memperhatikan dan meningkatkan kualitas Sumber Daya Manusia yang dimiliki baik padatingkatan sistem, kelembagaan, maupun individu dengan mengikutsertakan perangkat desa dalampelatihan-pelatihan yang berhubungan dengan akuntansi dan pengelolaan keuangan 
Value Jurnal IImiah Akuntansi Keuangan dan Bisnis

Vol. 1 No. 1 Bulan April - September 2020

daerah, agar dapat mendukung penyajian laporan keuangan yang tepat waktu.

Berdasarkan beberapa penelitian di atas inti dari permasalahan pelaporan keuangan program dana desa adalah pada kualitas sumber daya manusia yang belum memadai sehingga terjadi kendala-kendala dalam membuat laporan keuangan danadesa.

\section{Kesimpulan dan Saran}

\subsection{Kesimpulan:}

Berdasarkan hasil penelitian dan pembahasan penelitian dapat disimpulkan bahwa:

1. Kualitas sumber daya manusia yang belum memadai

2. Masih minimnya pelatihan-pelatihan untuk mengembangkan kemampuan aparat desa dalam membuat laporan keuangan program dana desa.

3. Kurangnya pemahaman perangkat/aparat desa dalam bidang akuntansi.

\subsection{Saran}

1. Peningkatan kemampuan perangkat desa dibidang pembuatan laporan keuangan perlu ditingkatkan dengan melakukan pelatihan-pelatihan teknis.
2. Alokasi dana desa sebaiknya juga di fokuskan pada pengembangan sumberdaya manusia.

\section{DAFTAR PUSTAKA}

Arif, Muhammad.2007. Tata Cara Pengelolaan keuangan Desa Dan Pengelolaan Kekayaan Desa. Pekanbaru : Red Post press.

Candra Kusuma Putra, Ratih Nur Pratiwi Suwondo.2016. Pengelolaan Alokasi Dana Desa Dalam Pemberdayaan Masyarakat Desa. Jurnal administrasi Publik. (JAP), Vol 1, No 6. Hal 1203-1212.

Heidjrachman, Suad Husnan. 2008. Manajemen Personalia. Edisi 4. Yogyakarta: BPFE.

IAI-KASP.2015. Pedoman Asistensi Akuntansi Keuangan Desa.Ikatan Akuntan Indonesia.

Ismail, M., Widagdo, A. K., \& Widodo, A.2016. Sistem Akuntansi Pengelolaan Dana Desa. Jurnal Ekonomi dan Bisnis, 19(2), 323-340. https://doi.org/https://doi.org/10.249 14/jeb. v19i2.336

Juklak Bimkon Pengelolaan Keuangan Desa.2015. Petunjuk Pelaksanaan Bimbingan \& Konsultasi Pengelolaan Keuangan Desa. Deputi Bidang Pengawasan Penyelenggaraan Keuangan Daerah Kompas.com. 2019. Total Dana Desa 20192024 Rp 400 Triliun. Error! Hyperlink reference not valid.. Diakses tgl 27 Desember 2019 pukul: 20:25 WIB Mangindaan, Joanne V. Dan Manossoh, Hendrik.2018. Kualitas Sumber Daya Manusia Pemerintah Desa Dalam Pengelolaan Dana Desa Yang Bersumber Dari Anggaran Pendapatan Dan Belanja Negara Di 
Value Jurnal Ilmiah Akuntansi Keuangan dan Bisnis

Vol. 1 No. 1 Bulan April - September 2020

Kecamatan Tabukan Utara Kab. Kepulauan Sangihe. Jurnal Lppm Bidang Ekososbudkum. Volume 4 Nomor 1 Tahun 2018 EdisiSeptember Marlinawati Dan Wardani, Dewi Kusuma. 2018. Pengaruh Kualitas Sumber Daya Manusia, Pemanfaatan Teknologi Informasi, Dan Sistem Pengendalian Intern Terhadap Ketepatwaktuan Pelaporan Keuangan Pemerintah Desa. Jurnal Kajian Bisnis Vol. 26, No. 2, 2018, $131-143$

Meutia, I., \& Liliana, L.2017. Pengelolaan Keuangan Dana Desa. Jurnal Akuntansi Multiparadigma, 8(2), 336-352.

http://dx.doi.org/10.18202/jamal.201 7.08.08.7058

Mitrapol.com. 2019. Kabupaten Tobasa Dapat Jatah Anggaran Dana Desa Rp 176 Miliar. https://mitrapol.com/2019/02/01/kab upaten-tobasa-dapat-jatah-anggarandana-desa-rp-176-miliar/. Diakses tgl 15 desember 2019 pukul 22:13 WIB

Moleong, Lexy J. 2007. Metodologi Penelitian Kualitatif. Bandung: PT. Remaja Rosda Karya.

Nyimas Latifah, Letty Aziz.2016. Otonomi Desa dan Efektivitas Dana Desa . Jurnal Penelitian Politik Vol 13 No 2. 2016

Peraturan Menteri Dalam Negeri No. 113 Tahun 2014, Pengelolaan Keuangan Desa

Peraturan Menteri Desa, Pembangunan Daerah Tertinggal, dan Transmigrasi Nomor 5 Tahun 2015 tentang penetapan Prioritas PenggunaanDana Desa Tahun 2015.

Peraturan Menteri Desa, Pembangunan Daerah Tertinggal, Dan Transmigrasi Republik Indonesia Nomor 16 Tahun
2018 Tentang Prioritas Penggunaan Dana Desa Tahun 2019.

Peraturan Pemerintah Nomor 43 Tahun2014 tentang Peraturan Pelaksanaan Undang-Undang Nomor 6 Tahun 2014 tentang Desa.

Sekaran, Uma. 2006. Metodologi Penelitian untuk Bisnis. Jakarta: Salemba Empat.

Sembiring, Febriady Leonard.2013. "Pengaruh Kualitas Sumber daya Manusia, Pemanfaatan Teknologi Informasi, dan Pengendalian Intern Akuntansi Terhadap Nilai Informasi Pelaporan keuangan Pemerintah Daerah (Studi Pada Satuan Kerja Perangkat Daerah Di Kabupaten Pasaman Barat)".Jurnal. Universitas Negeri Padang.

Solikhah, B.; Sabowo, A.Yulianto .2018. Mewujudkan Akuntabilitas Pengelolaan Dana Desa dengan Aplikasi Sitem Keuangan Desa (SISKEUDES). Proceeding SNKPPM Vol 1

Srirejeki, Kiky.2015. Tata Kelola Keuangan Desa.Jurnal akuntansi dan bisnis $\underline{\mathrm{Vol}}$ 15, No 1 (2015)

Triani, Ni Nyoman Alit Dan Handayani, Susi. 2018. Praktik Pengelolaan Keuangan Dana Desa. Jurnal Akuntansi Multiparadigma (Jamal) Volume 9 Nomor 1 Halaman 136155 Malang, April 2018

Undang-Undang Desa Nomor 6 Tahun 2014 Tentang Desa.

Wayan, I .2016. Efektifitas Pengelolaan Alokasi Dana Desa Pada Desa Lembean Kecamatan Kintamani, Kabupaten Bangli Tahun 2009-2014

Wijaya, Endra Dan Roni, Mochamad Firmansyah.2019. Praktik Pengelolaan Keuangan Desa Dan Faktor-Faktor Yang Memengaruhinya. Jikh Vol. 13 No. 2 $\begin{array}{llll}\text { Juli 2019: } 165 \quad-184 & -16\end{array}$ 
Value Jurnal IImiah Akuntansi Keuangan dan Bisnis

Vol. 1 No. 1 Bulan April - September 2020

Http://Dx.Doi.Org/10.30641/Kebijak an.2019.V13.165-184 